\title{
RELECTURA DE LA ÉGLOGA II
}

\author{
ÁNGel García GaLiano \\ Universidad Complutense
}

Madrid

A Carmen Kaiser

\section{LA INVENCIÓN DEL RENACIMIENTO EN ESPAÑA}

En el prólogo al Libro Segundo de las poesías de Boscán y Garcilaso, la famosa Epistola a la duquesa de Soma, el poeta catalán explica su consabido encuentro granadino con Andrea Navaggero y su decisión de comenzar a trobar al itálico modo, los nuevos odres petrarquistas y neoplatónicos que introducían en las lenguas romances una distinta forma de inventar, de concebir el universo. Entusiasmado por los resultados que propiciaba el nuevo arte, el educador de don Fernando, el tercer duque de Alba, y amigo del toledano Garcilaso, hace partícipe a su colega de la buena nueva, quien no sólo lo emula de inmediato, sino que lo supera y logra, en apenas diez años, el milagro de consolidar la nueva lengua poética y convertir su exigua obra en el modelo incuestionable por el que hubo de transitar la poesía española de los siglos venideros.

En efecto, con apenas cuatro mil versos y en apenas diez años, Garcilaso de la Vega «inventa» (en sentido etimológico) el Renacimiento en España. Y sin embargo, Garcilaso ha sido víctima, y sus efectos perduran casi hasta nuestros días, de una doble usurpación; la primera, de orden métrico y ecdótico, tuvo lugar en su propio siglo, apenas unas décadas después de su temprana muerte; la segunda es fruto de la crítica biografista y postromántica. De sendas tergiversaciones han dado cuenta ya eminentes estudios y especialistas en la materia (Lázaro Carreter, Iglesias Feijoo, Francisco Ávila), me limito a esbozar el estado de la cuestión: 


\section{LA DOBLE USURPACIÓN DE GARCILASO}

La primera «lectura interesada» de la obra del poeta toledano tiene lugar ya en su siglo, precisamente por quienes (Brocense, Herrera) se arrogan la tarea de encumbrarlo como modelo: las evidentes (¿pero tantas?) erratas de la editio princeps, el deseo de mostrar erudición, la lectura que ambos hacen «desde la consolidación» métrica, estética del Renacimiento componen un Garcilaso limado de asperezas, regularizado, armonizado seguramente a tenor del gusto y la perspectiva de finales del siglo XVI y no desde su irrupción turbadora y transgresora, la de quien está todavía probando las nuevas formas de trobar y revoluciona la literatura peninsular con la asunción del «yo» petrarquista, el poeta que introduce la lira, la oda burlesca, la temática amorosa neoplatónica, en quien se puede constatar la fascinación que le produce su encuentro italiano (real o a través de los libros con poetas y humanistas como Varchi, Tasso, Castiglione o Sannazaro, capaces de ahondar desde nuevos ámbitos en la revolución literaria acaecida en Italia en la centuria anterior: cuando Garcilaso llega a Nápoles, aún está fresco el dolor por la muerte de Jacopo Sannazaro, sin cuya $\mathrm{Ar}$ cadia es imposible comprender la génesis de sus tres églogas. Pero además conoce allí los nuevos cauces (anti)petrarquistas y revitalizadores como los que practica Benedetto Varchi, lejos de la dictadura ciceroniana y esterilizante que propugnaba Bembo y su cohorte de fríos imitadores simples del de Arezzo.

Si alguien se plantea por qué la poesía castellana del XVI tiene más calidad, en general, que la italiana de idéntico período, la respuesta está en que en España vencieron las propuestas innovadoras (desde la imitación compuesta y la emulación) de Garcilaso, mientras que en Italia, por el contrario, cristalizaron los dictados de Bembo y sus secuaces.

Pues bien, esa propuesta radicalmente innovadora, ecléctica, irónica y transgresora todavía en 1542, fecha del prólogo al Libro II de sus poesías, ha de ser defendida por Boscán contra los ataques casticistas de los defensores del «metro (y las esencias cancioneriles) castellano». Sin embargo, en la década de los setenta, para Herrera y el Brocense, Garcilaso es modelo indiscutible de imitación: la lectura que del toledano hacen ambos, en su intento por explicar al maestro, es a lo que he llamado primera usurpación de Garcilaso: en su intento por armonizar y regularizar al poeta, para ellos muy deturpado en las ediciones previas, seguramente aherrojaron sus propuestas en una horma visiblemente más estrecha (menos «presuntuosa» y más «proporcionada») que la que él mismo se había audazmente fabricado.

En suma, allí donde el maestro se salía de los cauces «previsibles» era sumariamente corregido, allí donde no se entendía, era obviado y, por úl- 
timo, allí donde su propuesta estética atacaba directamente el «buen gusto» tridentino y clasicista de finales de siglo era vituperado y censurado.

Lecturas claramente distorsionadoras del espíritu y la forma originaria como las que se han hecho de la Ode ad florem Gnidi, las églogas, las canciones II y III, o algunos sonetos ${ }^{1}$ nos han proporcionado un texto más «ortodoxo» (desde la óptica del comentarista) y menos arriesgado, que acaso desea difuminar los titubeos iniciales del poeta, pero que oculta también las posibilidades tácitas que «aún bullendo estaban» en la concepción poética profundamente valiente e innovadora del joven Garcilaso.

Los comentaristas, en fin, se encargan de abrillantar, pulir y sancionar las intuiciones y hallazgos poéticos de Garcilaso que, cuarenta años después, eran carta común entre sus epígonos; sin embargo, los eruditos cancerberos de la clasicidad se cuidaron bien de regularizar, tapar y reinterpretar las arriesgadas propuestas que el de Toledo dejó en el camino, meros titubeos de principiante o, en algún caso sin duda, senderos no explorados por sus sucesores.

Dicho de otro modo y con voluntad recapituladora: la poética que se extrae de la obra de Garcilaso es aquella que corrobora el uso poético de los «herrera» de turno; todo aquello que no encaja con la concepción poética del comentarista se elimina. De esa manera tan bienintencionada como falaz, se perpetra ya en el siglo XVI la primera usurpación de Garcilaso.

La segunda usurpación, mucho más conocida y patética, tiene que ver con el paralogismo biográfico e historicista pseudorromántico que cree encontrar encarnado en el texto el ánima del poeta, que en vez de tal (en vez de estar construyendo un cancionero petrarquista, por ejemplo, es decir, ficcionalizando en una historia de amor el yo poético) parece un tierno adolescente redactor de diarios. La usurpación, muy astutamente denunciada por Iglesias Feijoo en un artículo admirable, consiste en leer los textos poéticos «como si» fueran biográficos, de manera que de ellos se extrae la (apenas conocida en otros documentos) historia del poeta, la cual (y aquí acaece la fechoría, desde el punto de vista hermenéutico) sirve para elucidar los textos de donde se ha extraído.

Es una historia muy vieja y hoy felizmente arrumbada, de la que fueron víctimas todos los poetas (el caso de Herrera es sonrojante, como ya explicó Cristóbal Cuevas en su edición a las poesías del sevillano) anteriores al Romanticismo. Hoy ya nadie, afortunadamente, osa una lectura del poeta tan ingenua, pero conviene recordar que todavía esa rémora al-

1 Véase sólo los casos más clamorosos: la primera estrofa de la Canción II, el problema que plantea la «irregularidad» de las estrofas 19 y 20 de la Égloga I, o los esfuerzos por regularizar, aun a costa del sentido, lecturas como la del inicio del soneto $\mathrm{XV}$. A las propuestas de Blecua o Rivers, al respecto, añádase la tesis doctoral de Ávila, la mejor aportación, hasta la fecha, que se ha hecho sobre el contexto métrico y poético de Garcilaso. 
canza a algunos manuales de bachiller y hasta universitarios, que «inventan» la lectura biográfica del texto para, desde ella, explicar el poema.

Dados estos supuestos, y reconocida la profunda originalidad (en el sentido renacentista) de Garcilaso, es lógico pensar que en los años napolitanos de aprendizaje y maduración poética probara diversos caminos, metros y temas: desde la fábula mitológica al testimonio épico, de la epístola humanista al atisbo de un cancionero petrarquista. Puede, como veremos, que la fascinación por el hermetismo neoplatónico lo llevara incluso al ambiguo e inquietannte territorio del orfismo y la poesía mistérica entendida como «amuleto mágico», en un sentido paralelo en poesía al practicado por Botticelli en pintura.

En Garcilaso, como en crisol, se van a concitar todos los temas y formas estróficas y métricas que conforman nuestro Renacimiento: hay un Garcilaso en octavas (con el precedente de Boscán) que llega a lo mejor de la literatura épica (pensemos en La Araucana); su espíritu burlesco y satírico esplende en Diego Hurtado de Mendoza y resuena aún en Quevedo; el uso e invención de la lira fulge en las odas de Fray Luis y el Cántico de Juan de Yepes; su construcción de un mundo eglógico en el cual la vida se eterniza en artificio y el arte da cuenta y proyecta un sentir vital pasa a través de Montemayor hasta Aldana, Cervantes, Góngora o Lope: como diría con su prosa transida y entusiasta don Dámaso Alonso, Garcilaso logra en la brevedad de su obra el milagro de concebir los embriones de toda la poesía renacentista, de modo que podría creerse que, de Cetina a Bocángel, toda la lírica en lengua castellana no es sino una glosa admirada y amplificadora de la poesía del toledano.

Por eso es tan injusto el reduccionismo con el que durante siglos hemos leído buena parte de su obra.

\section{LA VIDA Y LA LITERATURA}

Hemos afirmado que la estancia italiana, y sobre todo napolitana, de Garcilaso fue esencial para la «invención» del Renacimiento en España: a los textos y autores aducidos en el epígrafe introductoria cabe sumar el de Trissino (autor de una poética ecléctica y transgresora esencial para conocer a Garcilaso, publicada en 1529). El Renacimiento postpetrarquista que Garcilaso importa se estaba forjando sobre una amplia base estética y textual que, básicamente, se puede resumir en tres grandes vectores: la filosofía neoplatónica, la tradición clásica y el petrarquismo.

La irrupción del neoplatonismo en Italia, a través de los escritos y el magisterio de Marsilio Ficino primero y Pico della Mirandola después, es un elemento esencial para poder interpretar los textos literarios o las obras de arte que nacen bajo su directo influjo. Afortunadamente, tanto para la 
pintura como para la literatura contamos ya con numerosas monografías que dan cuenta de esta impresionante asimilación de las tesis neoplatónicas, tanto en su vertiente más explícitamente cristiana, como en su faceta esotérica, hermética y gnóstica. Es este, por cierto, un ámbito menos explorado en las influencias del toledano y que sin embargo será de capital importancia para nuestro intento de «explicación global» de la Égloga II que, digámoslo cuanto antes, amén de incomprendida, o por ello mismo, ha sido abandonada a su suerte cuando ocupa casi la mitad del total de la producción del poeta y es, a mi juicio, su obra más importante (no sólo la más ambiciosa, pues ello es evidente), sin la cual es difícil comprender «el proceso» de la literatura renacentista (épica, pastoril y aun «mística $\left.{ }^{2} \gg\right)$.En efecto, con ser evidente, aún no se ha hecho suficiente hincapié en la influencia de la cosmovisión neoplatónica (a través no sólo del De amore de Ficino, sino también a partir de las teșis de Castiglione en su Cortesano), gastando buena parte de la pólvora hermenéutica en salvas biografistas y presuntos amoríos portugueses, cuando lo cierto es que la mayor parte de la producción poética de Garcilaso no trata de ese asunto: este reduccionismo con el que leemos al poeta es el que nos hace pasar por alto más de la mitad de sus versos y cebarnos hasta el paroxismo en cuestiones sin duda secundarias: si Salicio es o no Garcilaso, si Nemoroso es o no Boscán, si Elisa esconde a Isabel Freyre, si también la dura Galatea es Isabel malmaridada con el gordo Fonseca, si Albanio es o no el duque de Alba o acaso su hermano pequeño plantean, bien mirado, la posibilidad de que todas estas impresionantes obras de arte no sean sino itextos de circunstancias! Flaco favor le hemos hecho a Garcilaso con este tipo de especulaciones: en vez de analizar con cuidado cómo lo leyeron sus discípulos (Hurtado, Cetina, Acuña, Juan de Yepes o el propio Herrera) o verificar de qué modo interpretó él a sus maestros: Virgilio, Horacio, Petrarca, Sannazaro... hemos construido casi toda la inmensa capacidad artística de su poesía sobre las movedizas arenas de una relación erótica más que dudosa con cierta cortesana lusitana.

\section{LA ÉGLOGA II: EL ESTADO DE LA CUESTIÓN}

Acaso pueda ser significativo advertir cómo uno de los máximos conocedores de la obra poética de Garcilaso, Antonio Prieto, no dedica ni una sola línea a esta composición, ni en su edición del Cancionero ni tampoco en su extraordinaria monografía La poesía española del siglo XVI, en la que solo alude a las «especiales características» de esta obra. Bien es cier-

\footnotetext{
2 Juan de Yepes leyó con más perspicacia esta égloga, como demuestra en algún pasaje importante del Cántico, que muchos de los comentaristas modernos y antiguos, que tienden a pasar por esta obra como por sobre ascuas.
} 
to que Prieto está ocupado en explicar la obra del toledano en clave de Cancionero petrarquista, pero la anécdota puede ser significativa sobre el «maltrato» tradicional que la crítica ha dispensado a un texto calificado por unos y otros como extraño, híbrido, mezcla de géneros, incomprensible, raro... y sin embargo, no se olvide, ese raro capricho ocupa casi la mitad de los versos castellanos del poeta. Aun sólo por una cuestión cuantitativa hubiera merecido mejor suerte, pero es que, además, estamos ante uno de los textos claves para la comprensión de este «Primer Renacimiento», cuya interpretación aún se resiente, en parte, de cierta opacidad crítica.

No voy a resumir aquí las interesantes y autorizadas aportaciones de Rafael Lapesa, S. Zimiz, Rivers o Inés Azar sobre la Égloga Segunda, diré sólo que mi modesta aportación a la elucidación de esta Égloga intenta iluminar aspectos que o bien han sido ya aludidos por ellos o, por el contrario, han pasado más desapercibidos en sus análisis.

Asumo del profesor Lapesa su intento por lograr armonizar las dos (o tres) partes casi independientes, formal y temáticamente, de que se compone la obra y su clara intuición (que él intenta demostrar con admirable perspicacia y desigual fortuna) de la enorme coherencia interna de la obra. No comparto con Zimic su visión de Albanio como amante respetuoso (sus intentos de propasarse quedan claros en los versos 820 y ss., así como la fogosidad de su «alter ego» don Fernando en versos que escandalizaron al bueno de Herrera), pero sí su percepción del desvarío del protagonista «a la manera cortesana» y su intuición de simetría e inclusión de una parte dentro de la otra, según se verifica en escenas como la ninfa dormida (versos 768 y 1370), así como la oposición-reflejo caza/guerra y el vínculo de Nemoroso como puente entre los dos ámbitos. Comparto con Inés Ażar su incisivo análisis de las diferentes partes de la obra, pero no así la conclusión (tibia, a mi juicio) a la que llega tras su minucioso estudio, según la cual el único vínculo de unión «entre las dos partes» sería la exposición de un caso ejemplar de desdicha (Albanio) enfrentado a un caso ejemplar de equilibrada perfección (duque de Alba), reconciliados ambos en una unidad superior, artística, por la magia órfica de Severo.

\section{LA ÉGLOGA II EN SU CONTEXTO HUMANISTA}

Asumiendo (o reflexionando sobre) las aportaciones de estos y otros grandes críticos como Margot Arce o R. O. Jones ${ }^{3}$, me permitiré apuntar

\footnotetext{
3 Para un repaso exhaustivo sobre el estado de la cuestión, puede ser útil la lectura de las notas a pie de página que se ofrecen en la aún reciente edición de Bienvenido Morros. Allí se encontrarán alusiones muy interesantes sobre las distintas interpretacio-
} 
un par de reflexiones que, acaso, contribuyan a colocar esta composición en el privilegiado lugar que le corresponde, una vez que se estime su organización como menos «incoherente» de lo que parece y seguramente más ambiciosa de lo que se ha dicho. Incoherencia o coherencia son siempre términos relativos respecto de una armonía superior y normativa a partir de la que se juzga. Y, en efecto, según la doble usurpación que se ha perpetrado en la poesía de Garcilaso, la Égloga II es un ejemplo de desproporción, hibridismo, mezcla de estilos, géneros y metros, se trata de una composición «extraña», atrevida, arriscada, poco asimilable según los estrechos cánones normativos de la erudición académica de finales del XVI, los fervores sentimentales del biografismo romántico y aun las leyes del petrarquismo ortodoxo -en tanto que esta composición desmentiría o pondría en cuestión, al menos, el intento de Garcilaso de componer un cancionero al uso.

No olvidemos que se trata de un texto con escenas dialogadas (y recordemos el pasaje del Quijote, II, $58^{4}$ en que se manifiesta explícitamente su carácter teatral). Una composición, en fin, que tiene elementos eglógicos, pero no es propiamente una égloga (sólo, en puridad, la mitad casi exacta de la misma), elementos dramáticos sin ser estrictamente una obra de teatro, composición épica por lo que se refiere al así llamado «panegírico del duque de Alba», narración cortés, histórica, mitológica, neoplatónica y hasta hermética, fruto claro de un momento de ebullición experimental que Garcilaso vive y aprehende de su estancia napolitana (inmediatamente posterior a la campaña alemana que como soldado vive en compañía del duque de Alba y de la que da heroica y artística cuenta en este texto), momento en el que los autores están cuestionando críticamente su relación con los textos clásicos, buscan nuevos caminos a través de una mirada oblicua sobre el canon ya consolidado y momento, en fin, en el que Garcilaso, como antes Poliziano, Sannazaro, Rafael o Botticelli, asume la mitología pagana como fuente de transmisión espiritual de una serie de valores (órficos, herméticos, neoplatónicos) que pueden competir con la espiritualidad y mitología cristiana y ocupar un lugar privilegiado en sus lectores.

Gracias a los estudios de Gombrich, Panofsky o Wind conocemos hoy lo evidente: que, en el ámbito de la recién instaurada Academia Platónica, una serie de artistas asume los postulados de la «nueva» filosofía ficiniana

nes o posibles modelos de cada parte de la obra, junto con reflexiones más cuestionables, como las reticencias (por motivos biográficos y i«psicológicos»!) que plantea la relación de Albanio con el duque de Alba. Me ocuparé de ello más adelante.

4 Pasaje de relativo interés exegético, no sólo al poner de manifiesto su carácter representativo, sino al vincular directamente el episodio con el mundo de la Arcadia y homenajear detalladamente el pasaje de la caza con red de los pájaros, traducido a la letra del texto de Sannazaro y que a Herrera se le antojaba prolijo y sobrante. 
para convertir sus innovadoras y refrescantes propuestas en imágenes y mitos que rivalizan y compiten por primera vez y en condición de igualdad con la iconografía tradicional cristiana: lo que después sería una evidencia (el uso de la mitología pagana y la tradición esotérica) y una práctica estética inocua, asimilada por el sistema, era todavía a principios del XVI una arriesgada e insolente manera de transmitir icónica, filosófica o poéticamente una serie de nuevos valores: manera, insisto, peligrosa de concebir la creación artística que tuvo episodios luctuosos y emblemáticos como la iconoclastia purificadora de un Savonarola (en cuyos autos de fe perecieron varios lienzos de Botticelli), la reacción ciceroniana y «antipaganizante» de la Roma anterior y posterior al «saco», tal y como se nos relata magistralmente en el estupendo Ciceronianus de Erasmo, o, por quedarnos en casa, las veleidades casticistas de nuestros poetas de cancionero que, con astucia torticera, saben rimar en sus libelos antiitalianizantes «pagana» con «luterana» y «petrarquista» con «erasmista».

Es exactamente en ese contexto en el que se debe insertar nuestra «égloga» (acaso hasta el nombre, como en su día la mal llamada Canción V, es quien genere un horizonte de expectativas que dificulta la verdadera elucidación del texto), un ambicioso «tour de force» del poeta español, que se atreve aquí, como en la Ode ad florem Gnidi, por ejemplo, concebida en este mismo ámbito transgresor napolitano, a proponer un camino de investigación artística sobre lo que debe ser el «nuevo estilo», cegado, por desgracia, casi en sus fuentes mediante una homologación clasicista tan bienintencionada como falsa, por parte de sus cultos y eruditos comentaristas.

\section{El SueÑo de Escipión: Venus, MaRte, MeRCURio}

¿Cuál es el tema de la «extraña» Égloga II? Esta composición de género híbrido y audaz versificación, de tono elevado y, a un tiempo, burlesco, que mezcla sin apenas solución de continuidad elementos épicos, mágicos, bucólicos y mitológicos. Y aun así, la obra manifiesta una profunda coherencia métrica y temática (como ya advirtió Rafael Lapesa), que aún puede ser incluso matizada desde la perspectiva que deseo proponer en las páginas que siguen.

En efecto, al hibridismo de formas métricas y géneros (épico, lírica petrarquista, bucólico y dramático) se suma la mezcla de temas, ambientes y argumentos: esta mezcla no es, empero, azarosa, y viene representada por el deseo de encarnar en obra de arte el ideal de construcción del hombre renacentista, del «cortesano» discreto, galante y sabio que acababa de traducir a maravilloso castellano su amigo Boscán. Era un tópico de la época, como bien sabemos, encarnado icónicamente en numerosas representaciones artísticas. 
Hay una especialmente significativa que puede iluminar nuestro acercamiento al texto, se trata de El sueño de Escipión, composición primeriza de un joven Rafael, sobre la que llama la atención Edgar Wind, en la que vemos al héroe al pie de un laurel, dormido $\mathrm{y}$, acaso, soñando con su fama. Dos mujeres se le acercan, la más hermosa le ofrece una flor, la otra, más severa, un libro y una espada: estos tres atributos simbolizan los tres poderes del alma humana, inteligencia, fuerza y sensibilidad. En el esquema neoplatónico de la vida tripartita estos tres dones configuran al hombre completo: el verdadero sabio no renuncia a ninguno de los tres, sino que trata en su vida de concitarlos mediante un crecimiento armonioso y un cultivo de cada uno de ellos que evite la hipertrofia de cualquiera de los tres: el exceso de sensibilidad lleva al extremo enfermizo de la voluptuosidad del melifluo buscador de los placeres carnales; el exceso de fuerza, a la rudeza del bruto soldado; y el cultivo exclusivo y obsesivo de la inteligencia al solipsismo erudito y vacuo.

Cada uno de estos atributos del ser humano está encarnado simbólicamente en un dios: la flor de la sensibilidad es Venus, la sabiduría del libro es Mercurio (Hermes) y la espada de la fuerza, por supuesto, es Marte. Esta tripartición se asociaba en el Renacimiento neoplatónico con otra historia mítica: la del juicio de Paris, el hermoso pastor, hermano de Héctor, convertido en soldado defensor de su patria sitiada «por culpa» de su unívoca elección voluptuosa: en aquel juicio, Hera encarnaba la sabiduría, Afrodita el placer, Atenea, la fuerza. El sabio no elige, sino que armoniza.

Según Marsilio Ficino, la felicidad consiste en el desarrollo integrado de esta triple opción, encarnada simbólicamente en las tres diosas o los tres atributos de Escipión: «Con razón no hay duda -escribe a Lorenzo de Medici- de que hay tres clases de vida: la contemplativa, la activa y la voluptuosa» y tres caminos, por tanto, que puede elegir el hombre para la consecución de la felicidad. Pues bien, seguir en exclusiva cualquiera de ellos a expensas de los demás no es sólo equivocado, sino blasfemo. Paris escogió el placer, Hércules el heroísmo, Sócrates la sabiduría. Lorenzo, sugiere Ficino (don Fernando, propondrá Garcilaso en su obra), «aconsejado por el oráculo de Apolo, no ha rechazado ninguno de los dioses. Él los vio a los tres y adoró a cada uno según sus méritos.»

Este pasaje de Ficino parece haber servido de modelo directo o indirecto, como ya viera Inés Azar, para uno de los momentos claves en la interpretación del significado global de la Égloga. Me refiero, al episodio en que el poeta describe el nacimiento de don Fernando:

Un infante se vía ya nacido

tal cual jamás salido d'otro parto (...)

Bajaban, d'el hablando, de dos cumbres

aquellas nueve lumbres de la vida 


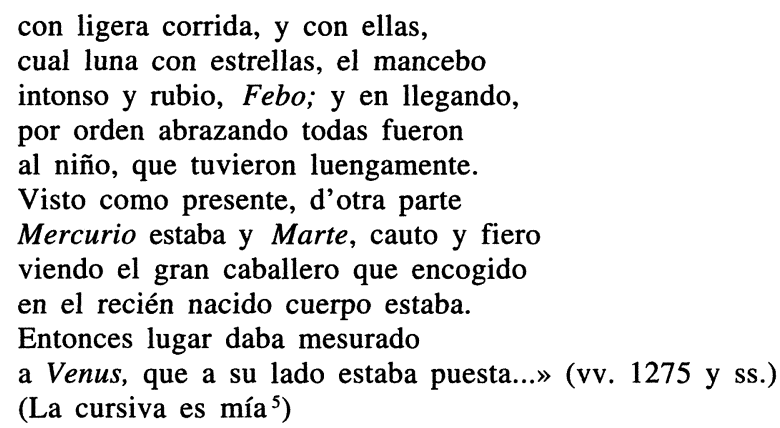

Si a la claridad simbólica de este pasaje allegamos el dato de que cumplimentar a un príncipe por su universalidad comparando su juicio al de Paris se convirtió en una fórmula retórica de presentación (tal como el cuadro de Rafael nos indicaba, pues en él su Paris/Escipión es un joven Medici que, cómo no, acepta los tres regalos de las diosas), estamos muy cerca de una interpretación global de la Égloga.

Es de todos sabido que el modelo fundamental de la misma (y de las otras dos en buena medida, habría que añadir) es la maravillosa Arcadia de Sannazaro, cuya lectura produjo una honda impresión en nuestro poeta hasta el punto de usarla desprejuiciadamente de modelo casi literal en muchos párrafos. Todo eso es bien conocido, así como también el negativo juicio que le mereció a Herrera el largo «plagio» del relato de Carino en la Prosa VIII. Lo que la crítica hasta ahora no había subrayado es el hecho de que, poco antes, Sincero, el narrador protagonista, describe a Carino de la siguiente guisa:

«Y este pastor venía de tal manera, que verdaderamente parecía el troyano Paris, cuando en las altas selvas entre sencillos rebaños vivía con su ninfa» (Prosa VI).

Acaso no sea ocioso recordar aquí que el Sincero pastor y narrador de la Arcadia no es otro que el propio Sannazaro en hábitos bucólicos y añorante de su patria partenopea. El pastor «de dentro de la obra de arte», del territorio bucólico, sigue siendo el cortesano (o el soldado) de fuera, cuando abandona o se recuerda fuera del ámbito atemporal eglógico. Su historia, muy parecida a la de Carino (como el «furor erótico» de Nemoroso emparenta con el de Albanio), es la que fuerza el relato de este «nuevo Paris», relato que traduce casi a la letra Garcilaso para ejemplificar el «caso» de Albanio. La conclusión es meridiana: Sincero es fuera de la égloga Sannazaro, como el nuevo Paris, aquí pastor con su ninfa, será soldado allí en su Troya sitiada: en tanto que Albanio es el Carino de esta

\footnotetext{
5 Citaré siempre por la edición maior de Rivers, que adjunto en la bibliografía.
} 
égloga (y más allá del tópico presentador de la época y de la circunstancia del homenaje meramente coyuntural) no cabe ya la menor duda de que «al otro lado» de ella, en el ámbito de la realidad de su Tormes, el Albanio amante desgraciado se transubstancia en el heroico duque de Alba, coronado de laurel y ardiente esposo de su «ninfa». Volveré sobre ello en seguida.

Pero sigamos adelante. Según la cosmovisión simbólica del neoplatonismo, cada uno de estos dioses reflejaba a su vez una dualidad: hay un Hermes esotérico y un Hermes exotérico, una Venus que encarna el amor contemplativo (humano y celestial) y una Venus ferina, como se explica en el De Amore; al igual que hay un Marte amable, el del gimnasio y la caza de los tiempos de paz que se contrapone al Marte airado y terrible de la guerra. Explica muy bien el propio Garcilaso esta dualidad en su dedicatoria de la Égloga I, dirigida, como todo el mundo sabe, al virrey de Nápoles, tío, a la sazón, del duque de Alba:

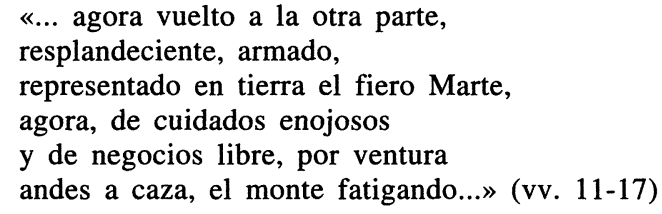

En efecto, el caballero renacentista es una suma armónica, bajo la advocación de Febo, de la fortaleza de Marte, el placer de Venus y la sabiduría de Mercurio, en sus dos variantes. El amor ferino por el cual pierde Albanio a Camila se trueca al otro lado en el ardiente (y honesto) deseo marital. El territorio marcial de la guerra terrible y fiera se convierte, a este lado, en el cultivo ocioso de la caza, el monte fatigando. La sabiduría órfica y hermética de Severo, que como quicio aparece a uno y otro lado (en el ámbito bucólico o literario y en el real o histórico), se substancia exotéricamente en la enseñanza cortesana de Boscán.

La Égloga II, de este modo, se organiza (como los cuadros de Rafael, Mantegna o Botticelli, sin ir más lejos) según esta estructura tripartita ${ }^{6}$ que aparece reflejada claramente en el genetlíaco de don Fernando y que se desarrolla en las écfrasis sucesivas, fragmento que representa, en miniatura y como en cifra, un resumen cabal de toda la composición.

6 No vamos a insistir ahora en la querencia neoplatónica del tres y en su uso por parte de Garcilaso en busca de la armonía simbólica: baste recordar, por ejemplo, como señala Antonio Prieto en sus estupendos análisis, que la Égloga I está compuesta de 30 estrofas, 12 para cada pastor, tres de enlace y tres para la dedicatoria. $\mathrm{O}$ que la Égloga III está construida también según este esquema tripartito a la hora de narrar las fábulas mitológicas: tres estrofas respectivamente para Orfeo, Dafne y Adonis y nueve $(3+3+3)$ para Elisa. 
Recordemos brevemente el argumento y sentido de esos versos (12791432) y acaso el lector intuirá también que en esa parte del cofre que el Tormes mostrase a Severo, y Nemoroso leyera después convertido en poema, está organizada profética y artísticamente (dos palabras clave en la Égloga, como se verá) el resto de la composición, del mismo modo que en numerosos cuadros de la época un pequeño retablo o pintura contiene, en miniatura, y «en abismo», el resto de la historia mitológica o bíblica que allí se representa? .

En esa parte del cofre Severo ha visto la infancia y adolescencia de don Fernando. Según una cuidadosa organización, en el primer tercio del texto, el que sucede durante la infancia y primera adolescencia del muchacho, es Mercurio (la sabiduría) quien protagoniza el relato, «corporeizado» por así decirlo en dos figuras claves en la educación del pequeño noble: el propio Severo, «espantado, yiendo el viejo/ que, como si en espejo se mirara,/ en cuerpo edad y cara eran conformes», es decir, el mago, el «Hermes esotérico», conocedor de los secretos y del arte de la sanación mediante el poderoso y órfico dominio sobre las palabras, encargado de transmitir «la doctrina/ al ánima divina deste mozo», inmediatamente después de lo cual sería Juan Boscán el encargado de enseñar al muchacho «la difícil arte cortesana».

Tras ello, Marte toma el relevo para mostrar al mozalbete la maña y el oficio de su dura tarea. Mas atenta está también Venus para retirar por un rato de tan áspero trato a don Fernando. En ese sentido, los versos 1369 a 1400 compendian, resumen y cifran las otras dos partes de la composición. El relato pastoril de los amores reprimidos primero, impulsivos después, ¿fracasados? de Albanio, es decir, dentro del tríptico, el territorio de Venus; y el relato épico-histórico de los hechos heroicos de armas logrados por el duque de Alba, testigo de los cuales, de algunos al menos, fue el propio Garcilaso; es decir, el territorio de Marte.

En efecto, Venus se lleva al joven del patio de armas donde se ejercita y «con él en una huerta entrada siendo,/una ninfa dormiendo le mostraba» (vv. 1369-1370), imagen que para Zimic, y comparto su criterio, anticipa toda la historia eglógica con Camila, la cual también aparece, a los ojos de Albanio, en forma de «ninfa dormida» (v. 768). El joven no se harta de mirarla y queda eternamente prendado de ella. Esa ninfa será, pronto, su esposa. En «medio», todo el episodio arcádico de unos amores improbables con ella y torpemente mancillados por la ferina impetuosidad de Albanio que habrá de ser, cómo no, curada por Severo. Volveremos sobre

7 Eso por no citar aquella maravillosa y enigmática Anunciación de un anónimo maestro flamenco en la que, al fondo de la casa de la piadosa virgen María, sobre el reclinatorio, puede verse ¡un crucifijo!, con lo que el ingenuo anacronismo se transforma en inquietante bucle temporal. 
ello. Porque en ese mismo instante de belleza contemplativa aparece Marte airado para mostrarle su triunfo futuro sobre el turco en Viena: la fortuna y la virtud otorgarán al cabo a don Fernando la corona de perfecto caballero renacentista, triunfador en los afanes de Venus y de Marte ${ }^{8}$ gracias a la sabiduría de Mercurio.

De ese modo «profético» y anticipatorio puesto en arte, resume el relato amoroso que acaece en la parte eglógica y pastoril de la obra y el episodio épico que sucede inmediatamente a continuación de este fragmento con la profecía final de la fama póstuma, más allá incluso de la muerte (vv. 1395-1400).

Como puede deducirse de este análisis, la relación con la Arcadia de Sannazaro es mucho más profunda entonces de lo que podría suponer un mero homenaje imitativo, se trata de ver en el nuevo Paris (esto es el duque de Alba, pastor en la «égloga», soldado en el «panegírico») al amante de la ninfa dormida dentro de la arcadia-huerto que le muestra Venus, ninfa Camila, cuyos amores son sólo coyunturalmente desgraciados (como los de Sincero-Sannazaro, o Carino) y fruto de la avidez ferina con que intenta propasarse el duque-pastor: al otro lado del espejo, en la vida «real» de don Fernando, triunfa el amor y esa misma fogosidad será bendecida por el poeta con una sorna y un desparpajo que, cómo no, lograron escandalizar a Herrera ${ }^{9}$.

\section{ARGUMENTO DE LA OBRA}

Contrariamente a las otras dos composiciones de aliento arcádico, las églogas I y III, ésta no tiene dedicatoria -toda ella, en puridad, es una larga y tácita dedicatoria a don Fernando, tercer duque de Alba-, sino que comienza abruptamente con la llegada al locus amoenus de Albanio, pastor herido por el rechazo de Camila. La presencia de la fuente, lugar de encuentro de los amantes y testigo de sus pesares, agudiza el dolor de su

8 La lucha simbólica entre el fiero Marte airado de la guerra y la Venus terrenal y epitalámica se encarna en la perfecta simetría de Garcilaso en forma de cinco adjetivos que describen a su esposa: «dulce, pura, hermosa, sabia, honesta» (v. 1416) ante la que la fogosidad del recién esposo no puede controlarse: «ardiendo y deseando estar ya echado», amoroso fuego en el que «todo ardiendo» (v. 1702) quema el horror de la recién terminada campaña, cincelada en un solo verso por cinco sustantivos definitivos: «muerte, daños, enojos, sangre y guerra» (v. 1710) que antecede justo en el pórtico a la bella descripción del abrazo marital con la esposa (vv. 1711 y ss.). Tales simetrías, que pueblan casi cualquier estrofa de la Égloga, confieren a la composición esa insólita e inasible belleza que, en mi opinión, acerca esta enigmática obra a, por ejemplo, uno de los cuadros más glosados y misteriosos de la iconología neoplatónica: me refiero, por supuesto, a La primavera, de Botticelli.

9 De «baxísimo y torpe verso» califica el 1416 en sus Anotaciones, «ardiendo y deseando estar ya echado». 
protagonista, que se entrega al sueño narcotizante. Salicio, su amigo, que acaba de regresar de la ciudad, elogia horacianamente la vida pastoril frente al rigor batahólico de la corte. Sucede, sin embargo, que también en la Arcadia anida la muerte (Et in Arcadia ego) y la desesperanza. Albanio se despierta con la misma angustia que el sueño le perdonara. Salicio le suplica que le relate el motivo y la causa de su desdicha. Comienza entonces la larga paráfrasis de la Prosa VIII de Sannazaro, la historia de los jóvenes Albanio y Camila, su pasión por la caza, el enamoramiento y terror de éste a revelar su pasión, el ímpetu amoroso que lo lleva a propasarse (espiritualmente, al pretender forzar el voto a Diana de la doncella, o ferinamente), el horror de Camila al descubrir su pasión y su huida y rechazo durísimo. La postración del amante víctima de su propia ofuscación (su furor erótico) y cómo la naturaleza, con un golpe de viento, lo salva del suicidio cuando ya había decidido renunciar a la vida. Salicio, pleno de sentido común, le reprocha su soberbia y desesperación por haberse dejado abatir tan presto, pero Albanio, indignado, rechaza la suposición de Salicio: «¿Qué sabes si ella agora/ juntamente su mal y el tuyo llora?»

Se alejan ambos de la fuente, a la que llega Camila, sus cristalinas aguas le traen el recuerdo de su historia, por ella sabemos que ama a Albanio «mas no como él pensaba», debido a su voto a Diana. El sueño (también a ella) la vence y Albanio, en los alrededores, la confunde con una ninfa. Al acercarse, como cualquier amante pasmado por la insólita belleza que yace sobre la hierba, duda un instante (como explica Ficino) entre el amor ferino y el humano, entre tocar o contemplarla (vv. 790 y ss.); ella se despierta con Albanio prácticamente encima y lo toma por un (¿nuevo?) intento de violación. Los versos siguientes están llenos de un exquisito doble sentido irónico y un sutilísimo humor sobre el que se relata los forcejeos de la pareja, ella por escabullirse y él por retenerla.

La huida definitiva de Camila propicia la final enajenación de Albanio: son los versos centrales de la égloga, como una amante desdichado invoca a Orfeo en su confusa pérdida de identidad: Salicio y Nemoroso son testigos de su locura e impiden que se arroje a la fuente. Este tipo de enajenación causada por el furor erótico, y asociada en este caso al mito de Narciso (ya estudiado por Rivers), se explica en el De Amore asociado a los otros tres, a saber: el de la poesía, el de los misterios y el de la adivinación (cap. XV). Ficino comenta cómo la corrupción de cada uno de ellos provoca la desgracia de la persona y su perdición ${ }^{10}$.

\footnotetext{
10 Dice Ficino: «Pero hay también cuatro afectos falsos que pueden imitar engañosamente a estos cuatro furores. Al furor poético, esa música vulgar, que sólo es agradable a las orejas. Al mistérico, la vana superstición de muchos hombres. Al profético, la falaz conjetura de la prudencia humana. Al del amor, el ímpetu del goce libidinoso (...) una caída de la vista al tacto» (Cfr. vv. 823-26 de la Égloga II, preñados de ironía burlesca).
} 
Estos cuatro furores (y sus nefastas o bienaventuradas consecuencias) están latentes a lo largo de toda la obra. En la primera parte prima el erótico, y en el amplio episodio de Severo se suscitan abiertamente los otros dos, el profético y el mistérico, sostenidos todos ellos por Febo, por el furor poético, tanto en el ámbito artístico de la primera parte: Parispastor (la Arcadia simboliza el espacio atemporal del arte frente a la realidad perecedera de la vida), como en el triple artificio que explica y profetiza la historia de la segunda, el «nuevo Paris»-duque de Alba. El salto de una realidad a otra se logra gracias a la enfermedad y pérdida del juicio de Albanio que, al verse reflejado al otro lado del espejo de la fuente, al otro lado de las palabras, se reconoce a sí mismo con los hábitos de Marte y la vara de Mercurio, esto es, el pastor y amante arcádico asume, en la realidad histórica, su condición de cortesano-soldado: Albanio se ve como (se transforma en) don Fernando, el duque de Alba.

Nemoroso se reconoce en la enfermedad de Albanio, en su furor ferino. Mientras consiguen reducir a su amigo, que vuelve a quedarse dormido, relata a Salicio su curación de manos de Severo, las especiales cualidades del sabio y el prodigio del que le hizo partícipe. Estamos de lleno en el ámbito de lo profético. El Tormes relata la vida de don Fernando y, de manera muy especial, la campaña de Viena; de nuevo aquí, como un espejo, los motivos del sueño, las comparaciones cinegéticas y la pericia de Garcilaso para conciliar Marte y Venus, uno de los grandes temas del Renacimiento, como es sabido. Tras la victoria militar de don Fernando, y su regreso a casa, en cuyos alrededores «estaba el mismo Tormes figurado» (el artista que, como Velázquez en Las Meninas, se dibuja a sí mismo), el panegírico culmina con una explosión de exuberancia por parte de la naturaleza, explosión que anticipa, por ejemplo, algunas liras de Juan de Yepes o de Fray Luis:

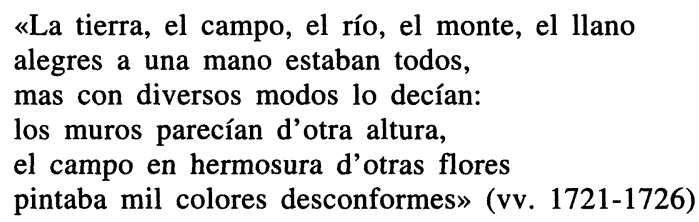

Ahí termina la visión de Severo, o la composición leída por Nemoroso y relatada oralmente a Salicio que nosotros leemos. Los siguientes cien versos (1742 y ss.) son los más enigmáticos (junto con los centrales, los que relatan el desdoblamiento de Albanio) de una obra ya de suyo compleja, abismal y ambigua, pues en ellos descendemos un grado y entramos explícitamente en el cuarto furor: el de los misterios; ahí hasta Severo tiene vedado el ingreso, «tu vista no es bastante a tanta lumbre», le dice el Tormes. 
Dada la cercanía de la Arcadia (cuyos elementos mágicos tanto se han difuminado, por cierto, en el texto de Garcilaso) y, al fondo siempre, el pensamiento hermético de Ficino (su Asclepius), cabe pensar que, además de todo lo dicho, la écfrasis-panegírico funciona también como amuleto órfico. Esta relación es evidente porque, frente a ciertos elementos del texto de Sannazaro (Prosa X), la magia natural de Ficino no tiene nada de demoníaco. Estos amuletos neoplatónicos (y entre ellos hay grandiosas, y enigmáticas, obras de arte, como La Giostra de Poliziano o La primavera de Botticelli) se convierten en un complejo talismán, una imago mundi elaborada para transmitir a quienes la observan tan sólo influjos saludables, vivificantes y antisaturnianos. De ahí el cuádruple asombro ante el prodigio ( $j$ ante el descenso eléusico en que hemos participado como espectadores incrédulos por la magia del Arte!), el asombro de Severo, «ya de ajena ciencia instruto», el de Nemoroso, «yo no podía hartarme allí leyendo», el de Salicio, «iQuien viese la escritura,/ ya que no puede verse la pintura!», y por supuesto el nuestro propio ante un «tamaño secreto» del que hemos sido testigos bajo la sencilla forma de una representación eglógica al uso.

La lectura de la última secuencia de la obra, jen la que no se pierde el sentido del humor y la sprezzatura hasta el mismo último verso!, nos coloca de nuevo en el ámbito pastoril, hemos descendido, como Orfeo, Odiseo, Eneas o Dante al reino secreto de la magia, la adivinación, la sanación y los misterios, ahora nos compete ayudar al amigo a que se vea reflejado en el amuleto para él fabricado de modo que al re-conocerse se sane y cumpla la misión que los siglos (y el auspicio de Febo) le tienen encomendada.

\section{LA ESTRUCTURA}

Según esta estructura tripartita, dividida en tres territorios, guiados todos ellos bajo la invocación de Febo-Apolo y sus musas, la «Égloga» presenta una disposición casi simétrica entre sus tres ámbitos en tanto que el segundo, el de Mercurio-Hermes, presidido por la fuente, es el vínculo de unión entre el territorio eglógico del arte, el mundo bucólico de Venus, y el ámbito épico-histórico de Marte en el que brillará la estrella del duque de Alba. Severo forma parte y es puente de unión entre ambos mundos, porque sana al pastor Nemoroso de su mal de amores y adoctrina al joven Fernando en la alta y secreta ciencia del espíritu, además de mostrar a Nemoroso el «poema» que compuso tras la revelación profética del Tormes y disponerse, en un futuro cíclico y «apuléyico», a sanar a Albanio.

La maestría de Garcilaso consiste en provocar un doble bucle en su obra, por un lado el episodio eglógico representa el ámbito de la literatu- 
ra, el artificio de la vida amorosa en fusión mítica con los símbolos de la tradición erótica neoplatónica. Dentro de ese mundo (primer bucle) y de la mano de Nemoroso, se presenta Severo, el sabio mago órfico en cuya iniciación se contiene (en forma artística, segundo bucle) la profecía del Tormes sobre la vida heroica de los Alba, dentro de la cual, puesta en abismo impresionante hasta para Severo - no digamos para el lector-, se representa, en una doble visión, a Venus resumiendo (mostrando) la parte eglógica de la obra (la ninfa dormida, pero con futuro final feliz epitalámico), y a Marte resumiendo (mostrando) al mancebo el triunfo de su espada sobre el invasor otomano y su gloria futura.

Pues bien, del mismo modo que en la parte protagonizada por Severo (el territorio de Hermes) está contenida en germen profético-artístico el resto de la obra, podemos apreciar cómo en la primera secuencia (bucólica) se contiene también, a su modo, el ámbito de Marte; ni más ni menos que en el extenso episodio cinegético (que es a lo que el cortesano se dedica en tiempos de paz, como vimos) y en la caracterización de Camila como una «Venus armada» con voto a Diana. Este «hermafroditismo» es típico del neoplatonismo artístico, y así vemos cómo la tríada Venus-Mercurio-Marte va generando, en sucesivas combinaciones, toda una serie de modelos mitológicos ${ }^{11}$ muy del gusto de la época, tales como Hermafrodita, Narciso, Dafne, Harmonía, etc.

Pero recuérdese que también en el llamado panegírico, hasta en su momento más cruelmente marcial, la fuerza venérea irrumpe en aquellos versos memorables que casi cierran la profecía y que relatan el encuentro de los esposos, como vimos.

Por tanto, y al igual que las Tres Gracias ${ }^{12}$ son la expresión de la unidad de Venus, el poema que relata la vida cabal de un cortesano renacentista contiene en armonía los tres dioses que la guían, cada uno de los cuales, a su vez, incluye especularmente en su seno a los otros dos en circular e infinita procesión ascendente. De esa forma nuestro Escipión dormido, el Albanio-duque de la obra, no renuncia ni a la flor, ni al libro ni a la espada, sino que sabe integrar el triple atributo en una unidad y armonía superior que guía Apolo, atento desde el instante mismo de su nacimiento al cuidado del infante, encomendado a las musas.

11 Esta «Venus armada» aparece de una manera explícita, pero allí en sentido irónico, casi burlesco, en la Ode ad florem Gnidi, que participa de un mismo aliento creador y audacia rupturista de la Égloga.

12 Cfr. vv. 1271-5, donde Garcilaso describe a las tres gracias «esculpidas» en lo que podría ser un recuerdo del medallón de Pico della Mirandola y, quizás, del cuadro de Botticelli. 


\section{LA FUENTE, EL RÍO, EL ESPEJO, EL REFLEJO}

Si el discreto lector ha seguido hasta aquí mi razonamiento, descubre que la parte central de la ¿Égloga? es el «territorio de Mercurio», del cual participan tanto el «venusino» Albanio, como el marcial duque de Alba, por medio de la figura quicio y vínculo de unión de Severo, sanador de Nemoroso (y se supone que de Albanio ${ }^{13}$ ) y educador de don Fernando.

Pero al igual que en el «territorio de Mercurio» encontramos el retrato germinal de las otras dos partes de la obra, hemos descubierto no sin perplejidad (aunque la maestría de Garcilaso nos inmuniza para el asombro) que en cada una de las partes se reflejan las otras dos. Pocas composiciones tan especulares como la Égloga II, dispuesta a provocar el pasmo ante el reflejo o la imagen no sólo de Severo ( 0 o del propio Tormes retratado en su retrato!), sino de Camila, que descubre a quien ama su amigo y compañero de caza al mirar su propio rostro reflejado en la fuente; o Albanio, quien enajenado se ve reflejado en esa misma fuente y cree que le han robado la mortal encarnadura.

La fuente, amén de ser un conocidísimo tópico sobre el encuentro erótico de los amantes en la poesía de todos los tiempos, ocupa aquí un lugar de excepción también desde el punto de vista estructural: en ese sentido la égloga está concebida dramáticamente como un decorado único de representación: durante toda la obra, el único espacio «real» es la fuente a la que llega el abatido Albanio y en la que se queda dormido. Allí le manifestará a Salicio la causa y el rigor de su tormento, dentro de cuyo relato, ahora evocada, volverá a aparecer como lugar de encuentro entre Albanio y Camila, lugar, en fin, de «revelación» de sus amores al ver su rostro en ella reflejado; allí llegará Camila, poco después, para quedarse también dormida y ser víctima de la impulsividad ferina de Albanio que intenta propasarse y luego habrá de pagar «mil años» la afrenta «de sola una hora el desatino» (v. 820); a ella querrá arrojarse enajenado Albanio (transmutado en nuevo Narciso ${ }^{14}$ ) tras perder ¿definitivamente? a la ninfa dormida, su amiga de juegos y caza; y de ella partirán Salicio y Nemoroso, al final de la representación, llevándose a hombros al amigo, maniatado y dormido, en busca de Severo.

Pero es que la estructura toda de la obra, como anticipé arriba, está planteada en forma de reflejo: el arte (la égloga) refleja, representa la vida,

13 Al que, como intentaré demostrar, no lo va a sanar de sus amores por la ninfa Camila, sino de su ferinidad e instintos bestiales, incompatibles con el sabio cortesano renacentista, que tiene que saber domeñar tales impulsos en la fogosidad del tálamo y no sobre la pureza diánica y dormida de la ninfa-pastora.

${ }_{14}$ Cfr. a este respecto el comentario de Marsilio Ficino en su De Amore, capítulo XVII, «De aquí se sigue aquel destino cruel de Narciso que canta Orfeo...» 
la cual, a su vez, viene representada (reflejada) en un cofre artístico cuya descripción profética resume y esboza, desde el episodio de la sabiduría y el vaticinio, las otras dos partes de la obra que hemos dado en llamar los territorios de Venus y de Marte. En la mitad justo de la obra, versos $942-$ 3 , y ochenta antes y después, es decir, unos 160 versos (el mismo espacio que el episodio de la educación del duque que vimos antes y algo más que el espacio que ocupa el episodio de los misterios), dividido a su vez en dos mitades casi simétricas por dos tipos de estrofa, tercetos encadenados primero y rima al medio después, aparece el episodio que, colocado en el centro, como en los cuadros neoplatónicos renacentistas, enmarca el resto de la acción y nos lleva de un territorio a otro:

- Del territorio del arte (historia de Albanio) al de la vida (historia del duque ${ }^{15}$ ).

- Del mundo eglógico al épico.

- Del ámbito erótico/cinegético al bélico/amoroso.

$Y$ en el quicio de ambos territorios especulares el motivo órfico y narcísico de la locura de Albanio a partir de la cual (y de su simbólico intento de arrojarse al abismo de las aguas para re-conocerse y recuperar su enarnadura mortal) Nemoroso puede insertar su relato sobre Severo, figura eje y mágica que comparte los dos ámbitos, el eglógico, a través de Nemoroso y el épico, como maestro del duque. Se trata del territorio de Hermes, de Mercurio, en cuyo eje (la mitad exacta del poema) laten estos versos de un Albanio enajenado que se contempla «al otro lado» del espejo-fuente:

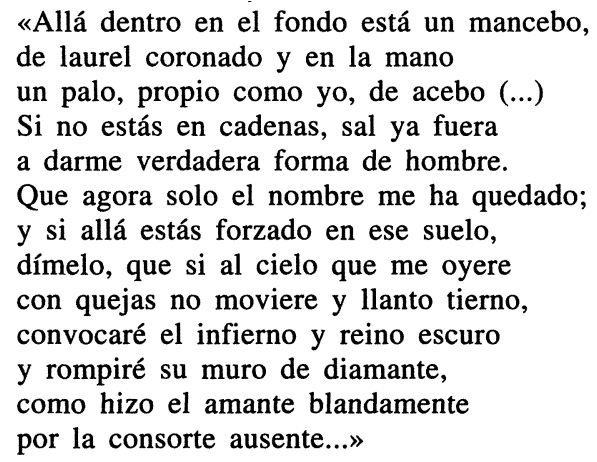

Justo en la mitad exacta de la obra, Albanio, roto de amor, abandonado por Camila, se contempla en la fuente (con la que se abre y cierra la

15 Sin olvidar, por supuesto, que los episodios de la vida del duque se representan en arte, triplemente ficcionalizados, cofre, poema y relato oral. 
composición y que ocupa sus 180 versos centrales) y se ve al otro lado ornado con los atributos de Marte y de Mercurio: el laurel y el caduceo ${ }^{16}$. El «nuevo Paris» domeñará el amor ferino gracias a la sabiduría de Mercurio (Severo), aprenderá el arte cortesano con Boscán, volverá victorioso del campo de batalla y gozará honestamente de su ninfa-esposa después de obtener la gloria militar contra los turcos.

\section{RECAPITULACIÓN EXPANSIVA}

A estas alturas, quedan pocas dudas de la enorme complejidad estructural y compositiva de la égloga, hora es de ir cerrando algunas de las hipótesis apuntadas en estas páginas. Sostuve al principio de este ensayo que una de las personas que mejor habían leído a Garcilaso fue Juan de Yepes. Vemos en su Cántico muchos homenajes directos e indirectos al prodigioso texto del toledano. También en su obra está la fuente, a la que acude la pastorcilla para auspiciar o suplicar el encuentro con su amado. También allí el reflejo de su rostro provoca el ingreso en otra dimensión, una vez consumada la unión de ambos, una dimensión que textualmente se verifica en un sorprendente e insólito cambio de atmósfera. Del pastoril y bucólico de las primeras once estrofas nos trasladamos, tras la unión, al ámbito urbano, cortesano, militar, de un rey y su esposa: también aquí el encuentro carnal y la posibilidad del amor se producen más allá del mundo arcádico y pastoril: ambas pastoras (Camila o la del Cántico) se convierten en la «esposa» y huelgan y se gozan en el amor de esposos. Hay una estrofa de Juan de Yepes que parece, hasta sintácticamente, reflejo de la ninfa-esposa dormida de la Égloga garcilasiana:

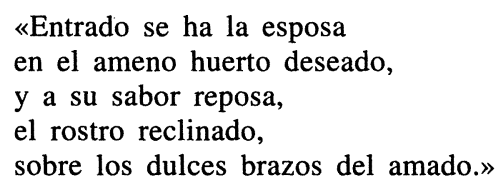

La pastora angustiada de «antes del encuentro en la fuente» es ahora la esposa reclinada felizmente en brazos del amado.

Hasta el uso del ingresivo reflejo parece un recuerdo del verso de Garcilaso: «con él en una huerta entrada siendo/ una ninfa dormiendo le mostraba», ninfa que no es otra que su futura esposa, en imagen profética dentro de un texto que es, todo él en sí, un vaticinio tallado por el río

16 Me ha sido imposible descubrir si, al margen de la rima, existe algún motivo para que el palo sea de acebo, planta druídica de carácter premonitorio y, en ese amplio sentido, hermética, pero ajena a la tradición mágica de ámbito neoplatónico. 
Tormes para el asombro del Severo espectador, el Nemoroso lector, el Salicio atento receptor de este prodigioso relato... y del perplejo lector «real» que somos cada uno de nosotros, a estas alturas sumidos en el vértigo de una puesta en abismo sublime y memorable: conscientes, sin embargo, al margen de los vértigos, de que un texto «despreciado» por los comentaristas valdría por sí solo para colocar a su autor ( $j$ si no lo estuviera!) en la más alta cima de nuestra literatura.

También en la Arcadia, Sincero descubre, gracias al relato de Carino - similar al suyo, pero de final feliz: de nuevo el espejo, la palabra que nos enseña nuestro verdadero rostro- que su amor «al otro lado», en su querida realidad de Nápoles, fuera del territorio atemporal de la Arcadia, puede ser posible. El pastor-cortesano o el pastor-soldado (en Albanio ambas cosas a un tiempo) vueltos aquí a la «verdadera realidad» no mediante los conjuros mágicos y demoníacos de un nigromante, sino sanados (esto es, regresados a su ser más profundo) por el poderoso encanto de las palabras talladas en cofre, poema o relato oral de una vida «reflejo» artístico de la propia: he ahí el sentido global de esta «Égloga», algo así como la autobiografía espiritual del poeta y uno de los testimonios líricos más impresionantes jamás escritos nunca en lengua castellana. Vale.

\section{BIBLIOGRAFÍA CITADA}

ARCE M., «La égloga II de Garcilaso de la Vega», Asonante, V, 1949.

ÁvilA, F., El texto de Garcilaso: contexto literario, métrica y poética, 2 vols., Tesis Doctoral, City University of New York, 1992. Ann Arbor: UMI, 1994.

AZAR, I., Discurso retórico y mundo pastoral en la «Égloga Segunda» de Garcilaso, Amsterdam, John Benjamins, 1981.

BleCUA, A., En el texto de Garcilaso, Madrid, Ínsula, 1970.

BosCÁN, J., Obras, Barcelona, PPU, 1991.

Cornelio AgripPa, Filosofía oculta, Buenos Aires, Kier, 1994.

Cuevas, C. (ed.), Fernando de Herrera, Poesía castellana original completa, Madrid, Cátedra, 1985.

CUlianU, Ioan C., Eros y magia en el Renacimiento, Madrid, Siruela, 1999.

FICINO, M., De Amore, Madrid, Tecnos, 1994.

-, Sobre el furor divino y otros textos, Madrid, Anthropos, 1993.

-, Teologia platonica, Bolonia, Zanichelli, 1975.

Gallego Morell, A., Garcilaso de la Vega y sus comentaristas, Madrid, Gredos, 1972.

García Galiano, A., La imitación poética en el Renacimiento, Kassel, Reichenberger, 1992.

—, «Poética implícita en Boscán», en Actas del X Congreso de la Asociación Internacional de Hispanistas, Irvine, Univ. de California, Tomo I, 1994, pp. 269-276.

GoMBrich, E. H., Imágenes simbólicas. Estudio sobre el arte del Renacimiento, Madrid, Alianza, 1983.

IGLESIAS FEIJOO, L., «Lectura de la Égloga I», Salamanca, Academia Literaria Renacentista, 1983, pp. 61-82. 
JONES, R. O., "The Idea of Love in Garcilaso's Seconde Eclogue», Modern Language Review, 46, 1951, pp. 388-395.

LAPESA, R., Garcilaso: estudios completos, Madrid, Istmo, 1985.

LÁZARO CARRETER, F., «La Ode ad florem Gnidi de Garcilaso», Salamanca, Academia Literaria Renacentista, 1983, pp. 109-126.

LEÓN HEBREO, Diálogos de amor, Barcelona, PPU, 1986.

Morros, B., (ed.), Garcilaso de la Vega, Obra poética y textos en prosa, Barcelona, Crítica, 1995.

PANOFSKY, E., Estudios de iconología, Madrid, Alianza, 1980.

PRIETO, A., La poesía española del siglo XVI, Madrid, Cátedra, 1984.

-, (Ed.) GARCILASo DE LA VegA, Cancionero, Barcelona, Bruguera, 1984.

RIVERS, E.L., «Nymphs, Shepherds and Heroes: Garcilas's Second Eclogue», Philological Quarterly, 51 (1972), pp. 123-134.

-, (Ed.) Garcilaso De la Vega, Obras completas, Madrid, Castalia, 1981.

SannaZaro, J., Arcadia, Madrid, Cátedra, 1993.

SEGRE, C., «Análisis conceptual de la I Égloga de Garcilaso», en Las estructuras y el tiempo, Barcelona, Planeta, 1976, pp. 163-184.

SHAH, I., La ciencia secreta de la magia, Madrid, Hiperión, 1989.

WIND, E., Los misterios paganos del Renacimiento, Madrid, Alianza, 1998.

YATES, F., Giordano Bruno y la tradición hermética, Barcelona, Ariel, 1994.

ZIMIC, S., «Las Églogas de Garcilaso de la Vega», Boletín de la Biblioteca Menéndez Pelayo, LIV, 1988, pp. 5-107. 